\title{
出 AERTAGE
}

OJS: http://heritage.iain-jember.ac.id

Pola Asuh Orang Tua dalam Mengembangkan Kepedulian Sosial Anak di Kabupaten Jember Tahun 2019

\section{Parenting Parents in Developing Children's Social Concerns at Jember Regency in 2019}

\author{
Ana Nurin Ramadhanty \\ MTs ASHRI \\ email: nurinramadhanty98@gmail.com
}

\begin{abstract}
The purpose of this study was to describe parenting patterns in developing children's social care. Parenting is a pattern of interaction between parents and children during care that has an important role in shaping the child's personality. Social care is a caring attitude towards the surrounding community. The research method uses descriptive qualitative research. The research location is Glengseran Hamlet, Suci Village, Panti District, Jember District. The method of selecting informants is purposive. Data collection techniques using observation, interviews, and documentation. Data analysis used Miles and Huberman's theories namely condensation, presentation, verification and conclusion. Data validity uses source triangulation.
\end{abstract}

\begin{abstract}
Abstrak
Penelitian ini bertujuan untuk mendeskripsikan pola asuh orang tua dalam mengembangkan kepedulian sosial anak. Pola asuh orang tua merupakan pola interaksi antara orang tua dan anaknya selama pengasuhan yang mempunyai peranan penting dalam pembentukan kepribadian anak. Kepedulian sosial merupakan sikap perduli terhadap masyarakat sekitar. Metode penelitian menggunakan penelitian kualitatif deskriptif. Lokasi penelitian yakni Dusun Glengseran Desa Suci Kecamatan Panti Kabupatrn Jember. Metode pemilihan informan dengan purposive. Teknik pengumpulan data menggunakan observasi, wawancara, dan dokumentasi. Analisis data menggunakan Teori Miles dan Huberman yakni kondensasi, penyajian, verifikasi dan kesimpulan. Keabsahan data menggunakan triangulasi sumber.
\end{abstract}

Kata kunci: pola asuh, orang tua, kepedulian sosial

\section{Pendahuluan}

Pendidikan merupakan usaha sadar dan terencana untuk mewujudkan suasana belajar dan proses belajar mengajar. Diperolehnya pertumbuhan kecerdasan dan potensi diri maka setiap anak diharapkan memiliki ilmu pengetahuan, kreativitas, sehat jasmani dan rohani, kepribadian yang baik, 
mandiri, dan menjadi anggota masyarakat yang bertanggungjawab. Pendidikan tidak bisa dipisahkan dan lepas hakikatnya dengan peserta didik dan pendidik, dimana peserta didik dan pendidik merupakan manusia yang penuh dengan usaha dan perbaikan (Munandar, 2001:123).

Orang tua mempunyai peran yang cukup besar dalam pembentukan kepedulian sosial anak. Orang tua yaitu komponen keluarga yang terdiri dari ayah dan ibu, dan merupakan hasil dari ikatan pernikahan yang sah yang dapat membentuk sebuah keluarga. Orang tua memiliki tanggung jawab berupa mendidik, mengasuh, melatih dan membimbing anak-anaknya untuk mencapai tahapan tertentu yang mengantarkan anak supaya siap dalam menjalani kehidupan bermasyarakat. Orang tua juga telah memperkenalkan anaknya kedalam hal-hal yang terdapat di alam sekitar dan menjawab berbagai hal tentang sesuatu yang tidak dimengerti oleh anak. Maka pengetahuan yang pertama kali diterima oleh anak adalah dari orang tuanya.

Kepedulian sosial tidak bisa terlepas dari proses belajar untuk menghasilkan tujuan yang diharapkan, yaitu memperoleh hasil pendidikan yang bagus dan memadai. Anak butuh mendapatkan proses belajar mengajar yang fundamental terlebih dahulu, misalnya bagaimana cara supaya anak belajar dengan senang, tidak tertekan, mudah menerima informasi, serta belajar adab dan sopan santun. Oleh sebab itu diperlukan adanya kesadaran orang tua bahwa setiap anak mempunyai kemampuan berbeda dalam bergaul, diantaranya dalam hal kepedulian sosial untuk mencapai hal yang diharapkan/ diinginkan oleh orang tua.

\section{Tinjauan literatur}

Pola asuh dapat diartikan secara etimologi yaitu pola berarti bentuk, tata cara, sedangkan asuh berarti menjaga, merawat dan mendidik. Sehingga pola asuh berarti bentuk atau sistem dalam menjaga, merawat dan mendidik. Jika ditinjau dari terminologi, pola asuh anak merupakan suatu pola atau sistem yang diterapkan dalam menjaga, merawat, dan mendidik seorang anak yang bersifat relatif konsisten dari waktu ke waktu. Pola perilaku ini dapat dirasakan oleh anak dari segi negatif atau positif.

Setiap orang tua mempunyai tugas dan tanggung jawab yang harus dipenuhi dalam mengasuh dan merawat anak-anaknya. Tugas dan tanggung jawab tersebut tidak berhenti sampai anak bisa makan minum saja tetapi akan berlangsung secara terus hingga anak-anak tersebut tumbuh dewasa dan 
mandiri. Keterlibatan orang tua dalam hal ini sangat dibutuhkan baik secara langsung maupun tidak langsung dalam mengasuh maupun memberikan kasih sayang kepada anak-anaknya, sehingga anak-anak dapat tumbuh dengan baik dan berkembang dengan baik secara fisik, kepribadian, emosional, maupun intelektual (Ulfah 2005:19).

Pola asuh orang tua disebut juga dengan pola interaksi antara orang tua dan anaknya selama pengasuhan yang mempunyai peranan penting dalam pembentukan kepribadian maupun fisik seorang anak. Menurut Mulyadi (2016:185) pola asuh dapat di artikan sebagai proses timbal balik baik berupa interaksi maupun komunikasi antara orang tua dengan anak. Interaksi dan komunikasi tersebut mencakup proses kegiatan memelihara yang dapat berupa pemberian makan, membersihkan dan melindungi serta proses sosialisasi yang dapat berupa mengajarkan perilaku yang umum dan sesuai dengan aturan dalam masyarakat. Proses ini melibatkan juga bagaimana seorang pengasuh (orang tua) mengkomunikasikan efeksi, nilai, minat, perilaku dan kepercayaan kepada anak. Terdapat beberapa indikator-indikator pola asuh orang tua yang memberikan ciri-ciri dari pola asuh tersebut. Pada hakikatnya, pola asuh terdapat 3 jenis yaitu pola asuh indulgent, pola asuh authoritatif dan pola asuh authoritarian.

Pola asuh Indulgent merupakan pola asuh orang tua yang biasanya memberikan pengawasan yang sangat longgar atau tanpa kontrol, orang tua tidak terlibat aktif dalam interaksi dan komunikasi kehidupan anak. Mereka memberikan kesempatan pada anaknya untuk melakukan segala sesuatu tanpa pengawasan dan memberikan sangat sedikit bimbingan kepada anak. Anak dari orang tua yang menerapkan pola asuh tipe ini sering bebuat tidak kompeten secara sosial. Mereka cenderung kurang mampu mengontrol diri, tidak cukup mandiri dan tidak termotivasi untuk berprestasi.

Menurut Ulfah (2005: 23) terdapat ciri-ciri pola asuh Indulgent yaitu sebagai berikut:

1. Membebaskan anak bertindak sendiri tanpa monitoring dan pembimbingan

2. mendidik anak secara acuh tak acuh, bersikap pasif dan tidak peduli

3. lebih mengutamakan kebutuhan dalam bentuk material saja

4. menuruti atau memberikan apa pun yang dilakukan anak (terlalu memberikan kebebasan untuk mengatur diri sendiri tanpa ada peraturan- 
peraturan dan norma-norma yang jelas dan tegas yang digariskan orang tua)

5. kurang memiliki keakraban dan hubungan yang hangat dalam keluarga

Pada pola asuh authoritathive, orang tua memiliki kecenderungan dalam hal menunjukkan adanya kontrol dan suasana kehangatan yang tinggi terhadap anak. Di dalam keluarga tipe ini terdapat aturan, sikap asertif, dukungan, fleksibilitas, serta self regulation sehingga anak lebih memiliki kebebasan dalam hal berkreasi dan mengeksploitasi berbagai hal dengan tetap adanya sensor batasan dan pengawasan dari orang tua. Kepribadian anak yang dapat terbentuk dalam pola asuh ini adalah keceriaam, kesenangan, kreativitas, kecerdasan, kepercayaan diri, terbuka dengan orang tua, tidak mudah stres ataupun depresi, serta berprestasi baik, tetapi ada kalanya merongrongatau menekan dan mengeksplotasi otoritas orang tua.

Pola asuh orang tua jenis Authoritative yang bersifat mempriotaskan kepentingan anak. Pola asuh ini bersifat mendorong anaknya untuk menjadi independen tetapi masih dalam batas mengontrol tindakan anaknya. Perbincangan tukar pendapat bersikap membimbing dan mendukung. Orang tua bersikap rasional, selalu mendasari tindakannya pada rasio atau pemikiran-pemikiran, serta bersikap realitas terhadap kemampuan anak. Anak yang orang tuanya otoritatif sering klai berperilaku kompeten secara sosial dan mereka cenderung mempunyai kemandirian.

Pada pola asuh jenis authoritatif orang tua tidak memaksakan keinginan mereka kepada anaknya, baik dalam hal pendidikan, pekerjaan, perjodohan, orang tua akan memberikan bimbingan dan tuntunan sesuai dengan minat dan bakat yang dimiliki anak, anak tidak memiliki paksaan untuk berprestasi atau bersekolah dari orang tua karena dengan pengertian dan pendekatan yang hangat dari orang tua, anak tau apa yang harus dilakukannya untuk membahagiakan orang tua tanpa harus dipaksa. Pola asuh tipe ini bersifat positif karena tidak akan merasa tertekan untuk sekolah atau memilih pendidikan dan berani bereksplorasi untuk menemukan hal-hal baru dan membuat anak memiliki motivasi untuk bersekolah yang tinggi sesuai dengan cita-citanya.

Menurut Ulfah (2005:23) terdapat beberpa ciri pola asuh Authoritative yaitu sebagai berikut: 
a) Menentukan aturan-aturan dan kedisiplinan dengan memperhatikan alasan-alasan yang dapat diterima atau rasional dan dapat dipahami oleh anak.

b) Memberikan arahan tentang pentingnya perbuatan baik yang harus dilakukan oleh anak dan yang tidak baik agar dihindari dan ditinggalkan.

c) Memberikan bimbingan kepada anak dengan penuh perhatian

d) menciptakan suasana harmonis dalam keluarga

e) menciptakan suasana interaksi yang komunikatif dengan orang tua, anak, dan sesama anggota keluarga

Pola asuh yang terakhir pola asuh authoritarian yaitu pola asuh dengan kontrol orang tua yang tinggi terhadap tingkah dan perilaku anak, tetapi kurangnya suasana kehangatan di dalam keluarga. Orang tua cenderung berperan sebagai seseorang yang wajib dituruti selayaknya seorang bos, menurut ketataatan, bersikap kaku dan penuh aturan. Akibat pola asuh jenis ini kepribadian anak yang terbentuk adalah mudah cemas, kurang percaya diri, kurang komunikasi, sulit mendapat keputusan, cenderung memberontak, mudah sedih dan tertekan, tetapi disiplin, mandiri, tanggung jawab dan idealis.

Pola asuh Authoritarian yang bersifat membatasi, memerintah dan menghukum. Pola asuh ini cenderung menerapkan standar yang mutlak wajib dipatuhi dan dituruti oleh anak. Apabila anak tidak mau melakukan apa yang diharapkan dan dikatakan oleh orang tua, maka orang tua melakukan tindakan yang responsif berupa hukuman yang dapat membuat jera seorang. Mereka membatasi dan mengontrol anak mereka dengan cara melakukan komunikasi yang berbentuk satu arah. Anak-anak dari orang tua otoriter umumnya sering kali tidak kompeten secara sosial, tidak bisa membuat inisiatif untuk beraktivitas, dan komunikasinya buruk.

Pola asuh Authoritarian memiliki dampak baik, dimana jika anak melanggar peraturan atau tidak menuruti perintah orang tua maka anak akan mendapat hukuman. Dalam kaitannya dengan pendidikan, apabila anak bolos sekolah dan melanggar peraturan sekolah. Orang tua akan memberikan hukuman dengan harapan menimbulkan efek jera, sehingga anak tidak lagi melakukan kesalahan yang sama dan akan memperbaiki sikap sesuai dengan apa yang di inginkan orang tua. Namun pola asuh tersebut memiliki dampak negatif bagi anak, karena anak memiliki motivasi yang tinggi untuk sekolah 
semata-mata karena perintah yang diberika orang tua.Anak cenderung menjadi penakut dan tidak memiliki inisiatif karena takut untuk mencoba hal-hal baru.

Menurut Ulfah (2005:27) terdapat beberapa ciri pola asuh Authoritarian yaitu sebagai berikut:

a) Anak harus mematuhi peraturan-peraturanyang ditetapkan oleh orang tua dan tidak boleh menolak atau membantah.

b) Orang tua sering mencari kesalahan anak dan kemudian menghukumnya.

c) Orang tua cenderung sering memberikan perintah-perintah dan larangan kepada anak.

d) Apabila terdapat perbedaan pendapat diantara orang tua dengan anak maka anak dianggap membantah atau membangkang.

e) Orang tua cenderung memberikan pemaksaan untuk bersikap disiplin.

f) Orang tua cenderung melakukan pemaksaan dalam segala sesuatu untuk anak-anaknya dan anaknya sebagai pelaksana wajib menuruti.

g) Tidak ada komunikasi yang harmonis antara orang tua dengan anak.

Adapun ketiga pola asuh tersebut memiliki kelebihan masing-masing dalam mendidik anak-anaknya. Indulgent memberikan keputusan yang benar yang telah dipilih oleh orang tua, Anak tidak perlu menanggung resiko. Authoritatif memberikan penghormatan atas pemikiran, perasaan serta apresiasi kepada anak atas keputusan yang diambil. Authoritarian memberikan dampak untuk sifat yang individual bagi anak sehingga anak mandiri atas pengawasan orang tua. Berbeda dengan teori bentuk pola asuh orang tua, dalam penelitian Diana Baumrind sangat berpengaruh. Iapercaya bahwa orang tua tidak oleh menghukum atau menjauh. Alih-alih mereka harus menetapkan aturan bagi anak dan menyayangi mereka. Dia telah menjelaskan empat gaya pengasuhan yaitu:

a Pengasuhan otoritarian adalah gaya yang membatasi dan menghukum dimana orang tua mendesak anak untuk mengikuti arahan mereka dan menghormati pekerjaan dan upaya mereka. Orang tua yang otoriter menerapkan batas dan kendali yang tegas pada anak dan meminimalisir perdebatan verbal.

b Penagusahan otoritatif adalah mendorong anak untuk mandiri namun masih menerapkan batas dan kendali pada tindakan mereka. Tindakan verbal memberi dan menerima dimungkinkan, dan orang tua bersikap 
hangat dan penyayang terhadap anak. Gaya ini biasanya mengakibatkan perilaku anak yang kompeten secara sosial.

c Pengasuhan yang mengabaikan adaah gaya di mana orang tua sangat tidk terlibat dalam kehidupan anak. Anak yang memilki orang tua yang mengabaikan merasa bahwa aspek lain kehidupan orang tua lebih penting dari pada mereka. Gaya ini biasanya mengakibatkan imkompetensi sosial anak, terutama kurangnya pengendalian diri.

Pengasuhan yang menuruti adalah gaya pengasuhan di mana orang tua sangat terlibat dengan anak, namun tidak terlalu membuat atau mengontrol mereka. Orang tua macam ini membiarkan anak melakukan apa yang ia inginkan. Hasilnya, anak tidak pernah belajar mengendalikan perilakunya sendiri dan selalu berharap mendapatkan keinginannya.

Kepedulian sosial menurut Ahmadi Abu dalam buku prikologi perkembangan adalah sikap mengindahkan atau memperhatikan segala sesuatu yang terjadi di masyarakat. Lebih lanjut makna kepedulian sosial adalah sikap merupakan suatu konsep psikolog yang komplek. Tidak ada suatu definisi yang diterima bersama oleh semua pakar psikologi. Satu yang dapat diterima bahwa sikap berakar dalam perasaan.

Kepedulian menunjuk pada suatu keadaan hubungan antara individu atau kelompok yang disarankan pada perasaan moral dan kepercayaan yang di anut bersama serta diperkuat oleh pengalaman emosional bersama. Tindakan sengaja untuk memberikan ketenangan dan mengatasi yang ada orang lain di dorong oleh rasa persamaan kemanusiaan, menyebabkan timbulnya kepedulian

Terkait dengan bentuk-bentuk kepedulian sosial Buchari Alma berpendapat bahwasannya bentuk-bentuk kepedulian sosial itu meliputi:

1) Lingkungan Keluarga

Seyogyanya manusia hidup sebuah keluarga adalah untuk mencari kebahagiaan dan ketentraman. Kemudian, apa yang sebenarnya diharapkannya tidak selalu berjalan seperti apa yang diharapkan. Diantaranya adalah kekerasan didalam rumah tangga (KDRT) yang dilakukan oleh suami kepada pasangannya atau pada anaknya sendiri, istri kepada suami atau anaknya sendiri. Hal ini sungguh telah melampaui batas kewajaran kemanusiaan. Kejadian-kejadian tersebut telah menggambarkan dengan jelas bahwa nilai-nilai kepedulian sesama anggota keluargasaat ini telah banyak 
yang pudar dan hilang. Sebaliknya mereka saling mengingatkan, mengajak pada hal-hal yang baik, seperti: mengajak membersihkan rumah, dan hal-hal yang dapat memupuk rasa persaudaraan dalam keluarga. Atau saling mengingatkan untuk tidak melakukan hal-hal yang negatif, seperti: seorang ayah mengingatkan pada anaknya untuk tidak main sampai larut malam, atau tidak bermain game berlama-lama. Karena khawatir hal itu akan mengganggu sekolahnya.

Keluarga yang merupakan lingkungan sosial terkecil seharusnya dipelihara sedemikian rupa, sehingga menjadi keluarga yang sakinah, mawaddah, warahmah. Hal ini menjadi penting karena akan sangat mendukung pada tingkatan masyarakat yang lebih luas termasuk dampaknya pada Negara. Kepedulian hal penting untuk menjadikan keluarga yang harmonis, rukun dan bahagia.

Lingkungan keluarga dalam peneliatian ini berfokus pada pola asuh orang tua dalam memberikan kasih sayang dan pengajaran kepada anak dalam mengamati kondisi sosial di masyarakat. Munculnya kepedulian sosial sangat diutamakan oleh lingkungan keluarga karna akan memberikan dampak positif baik secara internal dan eksternal.

2) Lingkungan Masyarakat

Kalau kita berkunjung kepedasaan yang memiliki tradisi kuat, maka kita akan melihat pemandangan yang menarik mengenai kepedulian sosial yang senantiasa mereka lakukan. Ketika ada suatu kegiatan yang dilakukan oleh satu keluarga, maka keluarga yang lain dengan tanpa imbalan segera membantu dengan berbagai cara. Misalnya saat mau mendirikan rumah. Anggota keluarga yang lain menyempatkan diri untuk berusaha mebantunya. Mereka membawa alat atau bahan bangunan yang sekiranya berguna.Bapakbapaknya ikut membantu membangun rumah, sedangkan ibu-ibunya membawa bahan makanan sesuai dengan kemampuannya. Ada yang membawa beras, pisang, atau bahan makanan lain yang dapat membantu meringankan yang punya pekerjaan. Sungguh pemandangan yang indah. Kerukunan antar warga masyarakat terlihat begitu nyata.

Berbeda dengan situasi saat ini terutama dikota-kota besar. Jarang sekali kita saksikan pemandangan yang menggambarkan kepedulian antar warga.Sikap individualisme lebih kelihatan dibandingkan dengan sikap sosialnya.Lingkungan masyarakat dalam penelitian ini berada di Dusun 
Glengseran Desa Suci Kecamatan Panti Kabupaten Jember. Dalam lingkungan masyarakat, kepedulian akan masyarakat menjadi point utama dalam kehidupan. Kepedulian mewujudkan kerukunan, gotong royong, kebersamaan dan kebermaknaan akan sosial.

Faktor-faktor yang menyebabkan kepedulian sosial antara lain:

1. Internet

Dunia kini semakin dekat ketika kita berhadapan dengan computer yang terhubung dengan jaringan internet. Tidak terbantahkan lagi dunia maya yang sangat transparan ini menjadi suatu pilihan untuk mencari informasi. Bahkan sebagai sarana hiburan yang membuat manusia lupa waktu. Karena terlalu asiknya menjelajah di dunia maya, tanpa disadari mereka tidak menghiraukan lingkungan masyarakat sekitar, sehingga rasa peduli terhadap lingkungan kalah oleh sikap individualisme yang terbentuk dari kebiasaan tersebut.

2. Sarana Hiburan

Kemajuan dunia semakin berkembang sering dengan kemajuan teknologi. Anak-anak lah yang akan menjadi "korban"-nya, karena mereka akan lupa waktu kalau tidak ada yang mengingatkannya. Dalam hal ini peran orang tua harus lebih ditingkatkan dalam mengawasi anak-anaknya. Karakter anak-anak yang suka akan permainan tentu tidak boleh dibiarkan begitu saja. Anak yang terlalu main game, akan mempengaruhi kepeduliannya terhadap sesama. Karena dia tidak berhungan secara langsung dengan sesamanya.

\section{Tayangan TV}

Kalau kita pehatikan, banyak acara-acara televisi yang kurang bagus. Diantaranya adalah acara-acara gosip yang belum tentu kebenaranya. Akibatnya secara langsung penonton diajari berkata bohong, memfitnah orang lain, menghakdir orang tua. Oleh sebab itu, kita harus pandai-pandai memilih acara di televisi. Dengan banyaknya acara sinetron yang jauh dari realita kehidupan masyarakat Indonesia pada umumnya bisa mempengaruhi para penontonya.

4. Masuknya Budaya Barat

Norma-norma dan tata nilai kepedulian ini semakin berkurang apabila masyarakat itu telah menerima pengaruh budaya barat yang 
bersifat immaterial dan cenderung berseberangan dengan budaya timur. Masyarakat yang kehilangan rasa kepedulian horisantalnya, akan kehilangan sebagian kemampuannya untuk dapat bersyukur, dan ini berakibat pada peneympitan psikologi dan dapat berubah ke arah ketidakpekaan (insentifitas) manusianya yang akhirnya dapat menghasilkan sistem sosial yang apatis.

Upaya meningkatkan kepedulian sosial antara lain:

1. Pembelajaran dirumah

Peranan keluarga, terutama didikan oranng tua terhadap anaknya akan sangat berpengaruh pada anaknya. Karena biasanya anak-anak itu anak meniru setiap tingkah laku orang tuanya. Oleh karena itu, orang tua harus menjadi contoh tauladan bagi anak-anaknya, agar kelak menjadi anak yang baik.

\section{Pembelajaran di lingkungan}

Banyak organisasi-organisasi di masyarakat yang dapat diikuti dalam rangka mengasah kepedulian sosial. Di antaranya adalah karang taruna yang anggotnya terdiri dari para pemuda pada umumnya. Belajar berorganisasi sangat penting, karena kita hidup di dunia ini dalam keadaan berkelompok. Berbagai macam karakter manusia dalam suatu kelompok akan sangat beragam. Oleh karena itu, kita akan memahami bagaimana hidup dalam suatu kelompok.

3. Pembelajaran disekolah

Organisasi-organisasi seperi OSIS, Pramuka, PMR dan lain-lain merupakan wadah pembelajaran bagi siswa untuk meningkatkan rasa kepedulian, baik sesama warga sekolah maupun masyarakat luas.

\section{Metode}

Metode penelitian menggunakan penelitian kualitatif dengan jenis kualitatif deskriptif. Lokasi penelitian ini difokuskan pada masyarakat Dusun Glengseran Desa Suci Kecamatan Panti Kabupaten Jember. Metode pemilihan informan dengan purposive. Teknik pengumpulan data menggunakan observasi, wawancara dan dokumentas. Analisis data menggunakan Teori Miles dan Huberman yakni kondenasis data, penyajian data,verifikasi dan kesimpulan. Keabsahan data menggunakan triangulasi sumber data. 


\section{Hasil \& Diskusi}

Berdasarkan paparan data yang telah disajikan dan dilakukan analisis, maka dilakukan pembahasan terhadap hasil temuan dalam bentuk interpretasi dan diskusi dengan teori-teori yang ada serta relevan dengan topik penelitian ini di sesuaikan dengan fokus penelitian yang ada. Adapun perincian pembahasan temuan penelitian ini adalah sebagai berikut.

\section{Pola Asuh indulgent orang tua dalam mengembangkan kepedulian sosial anak di Dusun Glengseran Desa Suci Kecamatan Panti Kabupaten Jember ahun 2019}

Pola asuh indulgent menurut teori Maria Ulfah menjelaskan bahwa, Orang tua menunjukkan kehangatan yang tinggi tetapi kontrol yang rendah terhadap perilaku anak.Orang tua sangat terlibat dengan kehidupan anak, cenderung bersikap lunak dan minim arahan, aturan tidak jelas, anak cenderung menjadi "bos".Dengan pola asuh ini anak menjadi manja, kurang dewasa, kurang teratur, egois, mudah menyerah, tidak disiplin, tetapi percaya diri, serta kreatif dan asertif. Indulgent pola asuh orang tua yang biasanya memberikan pengawasan yang sangat longgar, orang tua tidak terlibat aktif dalam kehidupan anak. Mereka memberikan kesempatan pada anaknya untuk melakukan sesuatu tanpa pengawasan dan memberikan sangat sedikit bimbingan kepada anak. Anak dari orang tua yang menerapkan pola asuh tipe ini sering bertindak tidak kompeten secara sosial. Mereka cenderung kurang bisa mengontrol diri, tidak cukup mandiri dan tidak termotivasi untuk berprestasi. Ciri-ciri pola asuh indulgent adalah sebagai berikut:

1. Membiarkan anak bertindak sendiri tanpa monitor dan membimbingnya

2. Mendidik anak acuh tak acuh, bersikap pasif dan masa bodoh

3. Mengutamakan kebutuhan material saja

4. Memberikan apa saja yang dilakukan anak (terlalu memberikan kebebasan untuk mengatur diri sendiri tanpa ada peraturan-peraturan dan norma-norma yang digariskan orang tua)

5. Kurang sekali keakraban dan hubungan yang hangat dalam keluarga

Dalam hasil penelitian pola asuh indulgent orang tua dalam mengembangkan kepedulian sosial anak di Dusun Glengseran Desa Suci Kecamatan Panti Kabupaten Jember tahun 2019, bahwa:

1. Bahwa orang tua kebanyakan acuh kepada anaknya. Sehingga anak-anak memiliki dunia dan acuh kepada tanggung jawabnya. Sikap anak itu 
disebabkan karna orang tua jarang berinteraksi secara rutin kepada anakanak dikarenakan orang tua bekerja untuk keluarga dan tidak menghiraukan pendidikan anak khususnya dalam meningkatkan kepedulian sosial anak.

2. Kebebasan kepada anak dalam segala hal baik berfikir, berencana dan mengambil keputusan. Orang tua menerima segala keputusan yang dipilih oleh anaknya, semata-mata agar anak-anaknya senang. Meski orang tua sebetulnya telah menyadari bahwa orang tua sibuk bekerja dan tidak memiliki waktu untuk menemani anak-anaknya setiap harinya. Kebahagian anak menjadi yang utama, meski dengan memberikan kebebasan dalam bertindak, menerima keputusan dan mengambil keputusan.

3. Pola asuh indulgent memberikan kebebasan kepada anaknya dan selalu menuruti apapun yang diminta sesuai dengan keputusannya sendiri. Orang tua tidak ingin jika anak-anaknya tidak masuk sekolah karna marah karna menginginkan sesuatu.

4. Pola asuh indulgent orang tua memberikan kebiasaan yang sering dilakukan seperti bersedekah kepada pengemis dan orang yang membutuhkan.

5. Hasil penelitian ini dapat disampaikan bahwa pola asuh Indulgent dalam mengembangkan kepedulian sosial anak di Dusun Glengseran Desa Suci Kecamatan Panti Kabupaten Jember diantaranya mengajarkan anak bersedekah, menolong, melihat teman yang sakit, namun orang tua dengan pola asuh ini hanya memberikan kasih sayang tetapi lupa untuk mengontrol anak ketika sudah memperoleh apa yang dia inginkan, karena orang tua ingin anaknya bahagia dan tidak malu kepada teman yang lain, orang tua tidak bisa mengontrol anaknya setiap waktu, karena mereka sibuk mencari nafkah. Hasil penelitian mendukung teori maria ulfah dalam pengembangan psikologi anak.

\section{Pola Asuh authoritatif orang tua dalam mengembangkan kepedulian sosial anak di Dusun Glengseran Desa Suci Kecamatan Panti Kabupaten Jember} Tahun 2019

Dalam teori Seto Mulyadi menjelaskan bahwa orang tua cenderung menunjukkan adanya kontrol dan kehangatan yang tinggi terhadap anak. Di dalamnya terdapat aturan, sikap asertif, dukungan, fleksibilitas, serta self regulation sehingga anak bebas berkerasi dan mengksploitasi berbagai hal dengan sensor batasan dan pengawasan dari orang tua. Dengan demikian kepribadian anak yang berbentuk adalah ceria, menyenangkan, kreatif, cerdas, percaya diri, 
terbuka dengan orang tua, tidak mudah stres dan depresi, serta berprestasi baik, tetapi ada kalanya merongrong otoritas orang tua.

Pola asuh orang tua authoritative yang memprioritaskan kepentingan anak. Pola asuh ini mendorong anaknya untuk menjadi independen tetapi masih membatasi dan mengontrol tindakan anaknya. Perbincangan tukar pendapat bersikap membimbing dan mendukung. Orang tua bersikap rasional, selalu mendasari tindakannya pada rasio atau pemikiran-pemikiran, serta bersikap realitas terhadap kemampuan anak.Anak yang orang tuanya otoriatif sering kali berperilaku kompeten secara sosial dan mereka cenderung mandiri.

Orang tua tidak memaksakan kehendak mereka kepada anaknya, dalam hal pendidikan, orang tua akan memberikanbimbingan dan tuntunan sesuai dengan minat dan bakat yang dimiliki anak, anak tidak memiliki paksaan untuk berprestasi atau bersekolah dari orang tua karena dengan pengertian dan pendekatan yang hangat dari orang tua, anak tau apa yang harus dilakukannya untuk membahagiakan orang tua tanpa harus dipaksakan. Pola asuh tipe ini bersifat positif karena akan merasa tertekan untuk sekolah dan berani bereksplorasi untuk menemukan hal-hal baru dan membuat anak memiliki motivasi untuk bersekolah yang sedang bahkan tinggi. Adapun ciri-ciri pola asuh Authoritative adalah sebagai berikut:

1. Menentukan peraturan dan disiplin dengan memperhatikan dan memperhatikan alasan-alasan yang dapat diterima dan dipahami oleh anak.

2. Memberikan pengarahan tentang perbuatan baik yang harus diperhatikan oleh anak dan yang tidak baik agar ditinggalkan.

3. Memberikan bimbingan dengan penuh perhatian

4. Dapat menciptakan keharmonisan dalam keluarga

5. Dapat menciptakan suasana komunikatif dengan orang tua, anak, dan sesama anggota keluarga

Berdasarkan hasil penelitian dalam pola asuh indulgent dalam mengembangkan kepedulian sosial, bahwa:

1. Orang tua selalu memberikan ruang anak untuk berkomunikasi dan samasama mengambil dan menyetujui keputuan. Dalam setiap keputusan orang tua selalu bermusyawarah untuk mengambil keputusan untuk jalan keluar atas apapun yang dihadapi anak. Beberapa contoh yakni saat memutuskan sekolah. 
2. Orang tua juga memberikan pandangan kepada anak untuk bagaimana berkomunikasi, memberikan bentuk kepedulian kepada orang lain juga bersikap kepada siapapun. Pola kerja sama yang sangat diutamanakan dalam pola asuh ini.

3. Orang tua menjelaskan bahwa komunikasi yang dibangun di keluarga adalah hal utama. Keluarga menyepakati terdapat jam-jam tanpa komunikasi atau bermain handphone dimana pada waktu tertentu.

Dari hasil penelitian dapat di sampaikan bahwa pola asuh Authoritative orang tua dalam mengembangkan kepedulian sosial anak di Dusun Glengseran Desa Suci Kecamatan Panti Kabupaten Jember di antaranya orang tua mengajak anaknya selalu berkomunikasi dan memutuskan pilihan yang terbaik dari hasil musyawarah dan mengajarkan anak selalu terbuka terhadap orang tuanya. Bentuk kepedulian yang muncul anak dan orang tua sama-sama peduli sosial dan orang tua mengjarkan untuk peduli kepada orang yang sedang membutuhkan, butuh pertolongan ataupun musibah. Hasil penelitian ini mendukung teori dari Seto Mulyani dalam pola asuh authoritatif orang tua.

Pola asuh authoritatif menjadi jalan tengah bagi orang tua dalam mendidik anaknya. Hal ini dikarenakan beberapa hal yang diantaranya adalah:

1. Lebih demokratis, pola asuh ini selalu berusaha memberikan keseimbangan misalnya diberikannya kesempatan bagi anak untuk melakukan pilihan dan mencoba berbagai hal namun dalam pelaksanaanya juga terdapat batasan yang jelas. Batasan ini juga harus disertai dengan alasan mengenai batasan tersebut dan anak juga tetap dilibatkan dalam membuat aturan yang akan diberlakukan di dalam keluarga. Hal ini terlihat sekali sisi demokratisnya.

2. Lebih bertanggung jawab, pola asuh ini menjadikan anak berpikir tentang dampak atau efek dari hal-hal yang dilakukan oleh anak atau tidak seenaknya sendiri.

3. Lebih percaya diri dan pandai beradaptasi, pola asuh ini memang tidak menggunakan kekerasan secara fisik sehingga anak lebih percaya diri dan merasa aman di dalam keluarga. Pola asuh ini dipercaya juga mampu untuk meningkatkan kemampuan pengelolaan diri atau emosi.

3. Pola Asuh Authoritarian orang tua dalam mengembangkan kepedulian sosial anak di Dusun Glengseran Desa Suci Kecamatan Panti Kabupaten Jember Tahun 2019 
Dalam teori Seto Mulyadi menjelaskan bahwa pola asuh authoritative dalam kontrol orang tua yang tinggi terhadap perilaku anak, tetapi rendah dalam kehangatan. Orang tua cenderung berperan sebagai "bos", menurut ketataatan, bersikap kaku penuh aturan.Akibat pola asuh ini kepribadian anak yang berbentuk adalah mudah cemas, kurang percaya diri, kurang komunikasi, sulit mendapat keputusan, cenderung memberontak, mudah sedih dan tertekan, tetapi disiplin, mandiri, tanggung jawab dan idealis.

Authoritarian Pola asuh yang bersifat membatasi, memerintah dan menghukum.Pola asuh ini cenderung menerapkan standar yang mutlak harus dituruti anak. Apabila anak tidak mau melakukan apa yang dikatakan oleh orang tua, maka orang tua tidak segan-segan untuk menghukum anaknya. Mereka membatasi dan mengontrol anak mereka dengan melakukan komunikasi satu arah.Anak- anak dari orang tua otoriter sering kali tidak kompeten secara sosial, tidak bisa membuat inisiatif untuk beraktivitas, dan komunikasinya buruk.

Pola asuh Authoritarian memiliki dampak baik, dimana jika anak melanggar peraturan atau tidak menuruti perintah orang tua maka anak akan mendapat hukuman. Dalam kaitannya dengan pendidikan, jika anak bolos sekolah melanggar peraturan sekolah. Orang tua akan memberikan hukuman untuk menimbulkan efek jera, sehingga anak tidak lagi melakukan kesalahan yang sama dan akan memperbaiki sikap sesuai dengan apa yang di inginkan orang tua. Namun pola asuh tersebut memiliki dampak negatif bagi anak, karena anak memiliki motivasi yang tinggi untuk sekolah semata-mata karena perintah yang diberika orang tua.Anak cenderung menjadi penakut dan tidak memiliki inisiatif karena takut untuk mencoba hal-hal baru.

Dalam hasil penelitian terhadap pola asuh orang tua dalam mengembangkan kepedulian sosial anak di dusun glengseran desa suci kecamatan panti kabupaten jember tahun 2019, yakni:

1. Orang tua memiliki peraturan untuk anak-anaknya. Orang tua memberikan penjelasan bahwa seluruh keputusan apapun itu diambil oleh orang tua baik sekolah, jodoh ataupun pekerjaan.

2. Orang tua menekanankan bahwa dia berhak untuk menentukan jalan hidup anaknya.

Dari wawancara dan observasi di atas dapat di sampaikan bahwa pola asuh Authoritarian orang tua dalam mengembangkan kepedulian sosial anak di Dusun Glengseran Desa Suci Kecamatan Panti Kabupaten Jember di antaranya orang tua 
selalu mengekang pilihan sang anak karena tidak sesuai kemauan orang tuanya, hingga anak mau tidak mau harus selalu menuruti apa yang diminta orang tua. Bentuk kepedulian yang muncul anak cenderung tidak peduli sosial, dikarenakan selalu orang tua yang mengambil keputusan anak ketika hendak melakukan apapun. Hasil penelitian senada dan mendukung penelitian Seto Mulyadi.

\section{Kesimpulan}

Pola asuh indulgent orang tua dalam mengembangkan kepedulian sosial anak di Dusun Glengseran Desa Suci Kecamatan Panti Kabupaten Jember tahun 2019, bahwa: (a) bahwa orang tua kebanyakan acuh kepada anaknya. Sehingga anak-anak memiliki dunia dan acuh kepada tanggung jawabnya. Sikap anak itu disebabkan karna orang tua jarang berinteraksi secara rutin kepada anak-anak dikarenakan orang tua bekerja untuk keluarga dan tidak menghiraukan pendidikan anak khususnya dalam meningkatkan kepedulian sosial anak. (b) kebebasan kepada anak dalam segala hal baik berifkir, berencana dan mengambil keputusan. (c) pola asuh indulgent orang tua memberikan kebiasaan yang sering dilakukan seperti bersedekah kepada pengemis dan orang yang membutuhkan.

Pola Asuh Authoritatif orang tua dalam mengembangkan kepedulian sosial anak di Dusun Glengseran Desa Suci Kecamatan Panti Kabupaten Jember ahun 2019 yaitu : (a) orang tua selalu memberikan ruang anak untuk berkomunikasi dan sama-sama mengambil dan menyetujui keputuan. Setiap keputusan orang tua selalu bermusyawarah untuk mengambil keputusan untuk jalan keluar atas apapun yang dihadapi anak. (b) orang tua juga memberikan pandangan kepada anak untuk bagaimana berkomunikasi, memberikan bentuk kepedulian kepada orang lain juga bersikap kepada siapapun. Pola kerja sama yang sangat diutamanakan dalam pola asuh ini. (c) orang tua menjelaskan bahwa komunikasi yang dibangun di keluarga adalah hal utama. Keluarga menyepakati terdapat jamjam tanpa komunikasi atau bermain handphone dimana pada waktu tertentu.

Pola Asuh Authoritarian orang tua dalam mengembangkan kepedulian sosial anak di Dusun Glengseran Desa Suci Kecamatan Panti Kabupaten Jember ahun 2019, yakni: (a) orang tua memiliki peraturan untuk anak-anaknya. Orang tua memberikan penjelasan bahwa seluruh keputusan apapun itu diambil oleh orang tua baik sekolah, jodoh ataupun pekerjaan. (b) orang tua menekanankan bahwa dia berhak untuk menentukan jalan hidup anaknya. Anak-anak cenderung tidak peduli sosial karena semua hal diputuskan oleh orang tua. 


\section{Referensi}

Ahmadi, Iif Khoiru. (2011). Mengembangkan Pembelajaran IPS Terpadu. Jakarta: Prestasi Pustaka.

Alma, Buchari dkk. (2010). Pembelajaran Studi Sosial. Bandung: Alfabeta Arikunto, Suharsimi. (1998). Prosedur Penelitian Suatu Pendekatan Praktik. Jakarta: Rineka Cipta.

Basrowi. (2009). Memahami Penelitian Kualitatif Jakarta: PT Rineka Cipta Daradjat, Zakiah. (2014). Ilmu Pendidikan Islam. Jakarta: Bumi Aksara

Djamal, M. (2015). Paradigma Penelitian Kualitatif. Yogyakarta: Pustaka Pelajar.

Husamah. (2017). Belajar dan Pembelajaran. Malang: Ikappi.

Madjid, Abdul. (2013). Perencaan Pembelajaran Mengembangkan Strandart Kompentensi Guru. Bandung: PT. Remaja Rosdakarya.

Mariana, Rita. (2010). Pengelolaan Lingkungan Belajar. Jakarta: Prenada.

Maria Ulfah. "Pengaruh Pola Asuh Orang Tua Yang Bekerja Terhadap Perkembangan Kepribadian Remaja", dalam Psikologi Perkembangan (Skripsi, Universitas Islam Negeri Syarif Hidayatullah Jakarta, Tahun 2015).

Mulyadi, Seto. Dkk. (2016). Psikologi Pendidikan Dengan Teori-teori Baru Dalam Psikologi, Jakarta: PT Rajagrafindo Persada.

Purwati, Eni. (2012). Pendidikan Karakter Menjadi Berkarakter MuslimMuslimah Indonesia. Surabaya: Kopertais IV Press.

Rohani, Ahmad. (1997). Media Interaksional Edukatif. Jakarta: CV. Rineka Cipta

Satori, Djam'an. (2014). Metodologi Penelitian Kualitatif. Bandung: alfabeta.

Sugiyono. (2010). Metode Penelitian Pendidikan Pendekatan Kualitatif, R\&D. Bandung: Alfabeta.

Sugiyono. (2014). Metode Penelitian Kuantitatif Kualitatif dan R\&D. Bandung: Alfabeta.

Susanto, Ahmad. (2013). Pengembangan Pembelajaran IPS di Sekolah Dasar. Jakarta: Rineka Cipta.

Wina, Sanjaya. (2011). Strategi Pembelajaran Berorientasi Standar Proses Pendidikan. Jakarta: Kencana Perdana Media. 